\title{
The Role of MRI in the Assessment of Placenta Previa and Abnormal Placental Invasion
}

\author{
HANY EL-ASSALY, M.D. \\ The Department of Diagnostic and Interventional Radiology, Faculty of Medicine, Cairo University
}

\begin{abstract}
Background: Placenta accreta is a serious condition that may threaten life with increasing incidence in the past years. Placenta accreta denotes abnormal placentation including placenta accrete (direct myometrial placental abnormal attachment), placenta increta (myometrial placental invasion) and placenta percreta (complete placental invasion within the uterine walls with or without extra-uterine extension).

Lower anterior uterine segment is the commonest site for placenta accreta. Multiple cesarean section with presence of placenta previa are considered the commonest risk factors for placenta accreta. The percent of developing placenta accreta is $24 \%$ in females having placenta previa and previous one cesarean section and rises with increased number of previous to cesarean sections.
\end{abstract}

Aim of Study: This study was done aiming at the clarification of the role of MRI in the assessment of the uterine walls' invasion by the placenta in cases with placenta previa.

Patients and Methods: Prospective study of 50 pregnant women with age range between 35 and 45 years old. They were all referred form the Gynecology and Obstetric Department with clinical and ultra-sonographic criteria of placenta previa with suspected abnormal placental invasion. The clinical and sonographic data were assessed followed by MRI study of the abdomen and pelvis for placental assessment.

Results: This study diagnosed placenta previa accompanied by accreta in $18 / 50$ cases \& placenta previa with no abnormal placental uterine walls' invasion in 32/50 cases. After correlation with surgical and histo-pathological reports, $100 \%$ of the cases showed true positive results regarding the MRI detection of placenta accreta as well as true negative results occurred in $81 \%$ of cases and false negative in $19 \%$ of cases.

Conclusion: MRI study offers a superior choice for assessment of placenta previa and detection of placental invasion of the uterine walls (accreta type).

Key Words: MRI-Placenta previa - Placenta accreta.

Correspondence to: Dr. Hany El-Assaly, E-Mail: hanyelassaly@gmail.com

\section{Introduction}

THE commonest etiology of post-partum hemorrhage is abnormal placental implantation leading to hysterectomy in many cases with growing risk of morbidity and mortality of the mother and fetus $[1,2]$.

The placenta that lies at the lower uterine segment close to the internal cervical os is termed placenta previa, as in normal conditions, the lower margin of placenta is at least $2 \mathrm{~cm}$ proximal to the internal cervical os margin $[\mathbf{1 , 3}]$.

Abnormal placental attachment to the uterine walls is generally termed Placenta Accreta (PA) referring to the relation of the chorionic villi to the uterine walls classified into accreta, increta and percreta $[4,5]$

Previous delivery by cesarean section, placenta previa as well as increased mother's age increase the possibility of placenta accreta development, with prior cesarean section considered as the most powerful redisposing factor for placenta previa and therefore placenta accreta $[\mathbf{5 , 6 ]}$. Placenta previa and prior uterine intervention play a major role in the occurrence of placenta accreta [1]

Early diagnosis of PA is of huge importance, as in most cases with PA antepartum hemorrhage occurs, therefore satisfactory pre-operative planning is obligatory $[5,7]$.

First diagnostic imaging modality for placental evaluation was Ultrasound, however with progres-

\footnotetext{
List of Abbreviations:

MRI : Magnetic Resonance Imaging.

PA : Placenta Accreta.

US : Ultra-Sound.

SE : Spin Echo Sequences.
} 
sive MRI advances, MRI rose as a competent diagnostic imaging modality in inconclusive cases by ultra-sound $[5,7]$.

\section{Patients and Methods}

\section{Patients:}

The study was approved by the Ethical Committee of Kasr Al-Aini Hospitals (Cairo University), and an informed consent was taken making sure the confidentiality of the enclosed the medical records is respected. The study design is prospective study. This study incorporated evaluation of 50 patients, their age ranged from 35-45 years during three years (from June 2016 till May 2019) who were prospectively recruited for this study. All patients referred from the Gynecology and Obstetric Department of Kasr Al-Aini Hospitals (Cairo University) were pregnant women with clinical criteria and ultra-sound findings suggestive of placenta previa.

\section{Methods:}

\section{Technique of MRI:}

MRI was done using a $1.5 \mathrm{~T}$ magnet scanner (GyroscanIntera; Philips Medical Systems, Best, the Netherlands) using phased-array pelvic coil. All the patients were imaged in the supine position, total study time ranged from 30 to 45 minutes. The SE sequences were done using respiratory triggering in order to minimize the maternal and fetal motion artifacts.

No contrast was given.

Descriptive analysis was done to generate frequency tables for various types of placenta previa and accreta.

\section{Images analysis:}

The placenta previa was classified by correlating the position of the placenta with that of the internal cervical os into:
a- Low-lying.
b- Marginal.
c- Complete.
d- Central [8].

Also classification of placenta previa with abnormal placental invasion into accreta, percreta and increta was performed by the degree of placental invasion into uterine wall [8].

The standard reference of this study was the criteria found at cesarean section and their correlation with MRI findings.

\section{Results}

Our study included 50 pregnant women of suspected placenta previa clinically and sonographicaly with age range from 35 to 45 years old and gestational age ranging from 25 weeks to 37 weeks.

According to MRI findings, cases were classified into patients with placenta previa with no abnormal placental invasion and placenta previa with accreta.

Placenta previa was found in all cases including 24 cases of complete centralis type Fig. (1), 20 cases of partial centralis type Fig. (2), 4 cases of marginalis type Fig. (3) \& 2 case of low-lying type Fig. (4). History of previous uterine intervention was given in 45 cases (90\% of cases) (Table 1).

Placenta accreta was diagnosed by MRI in 18 cases including 13 patients with placenta accreta, 4 patients with placenta percreta and 1 patient with placenta increta Fig. (5).
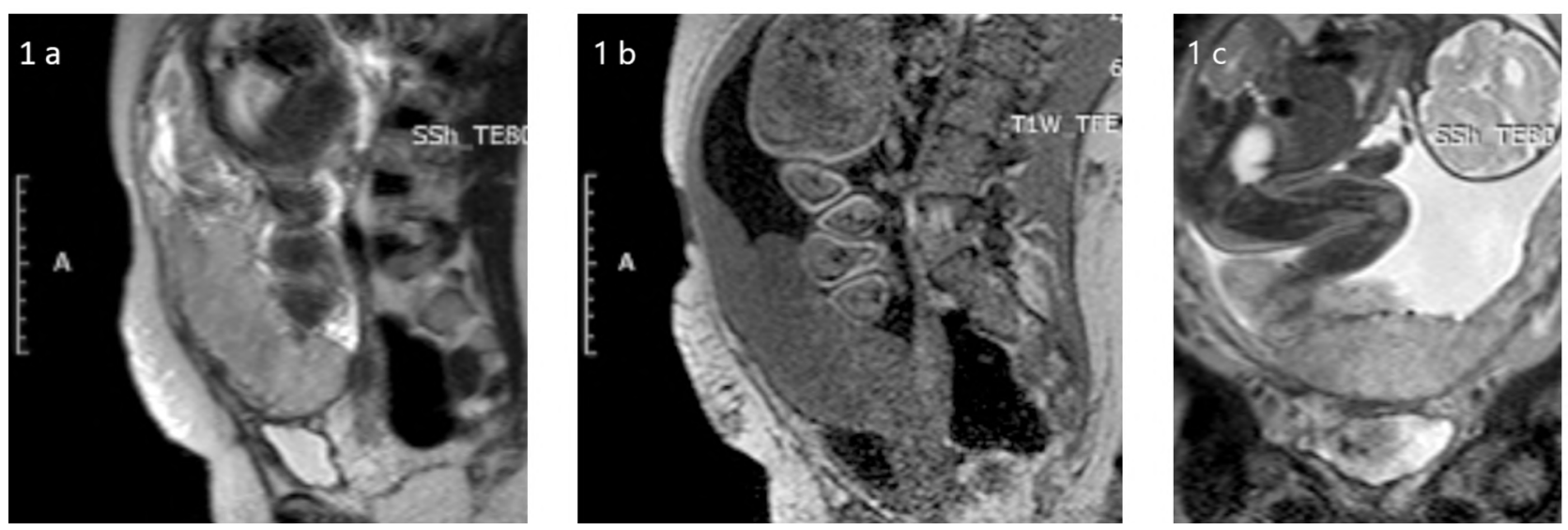

Fig. (1): A pregnant 36 years old female giving history of previous caesarian section with placenta previa complete centralis and evidence of accreta. (A) Sagittal T2 WI's , (B) Sagittal T1 WI's and (C) Cornal T2 WI's. 


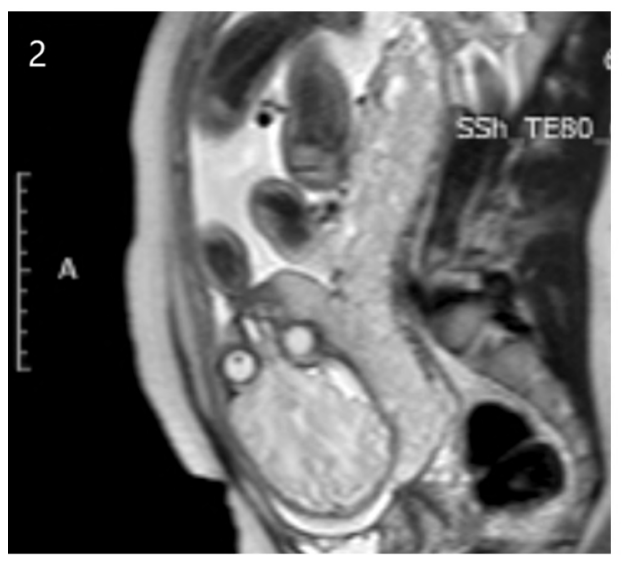

Fig. (2): A pregnant 38 years old female giving history of previous caesarian section with placenta previa partial centralis and no evidence of accreta. Sagittal T2 WI's.

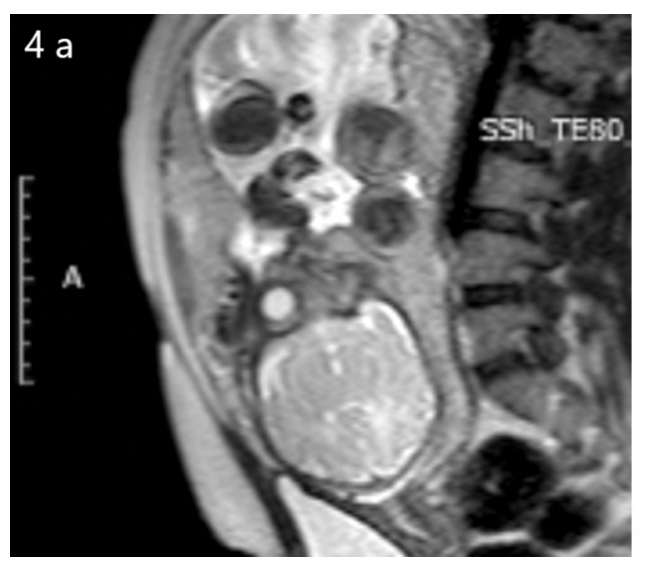

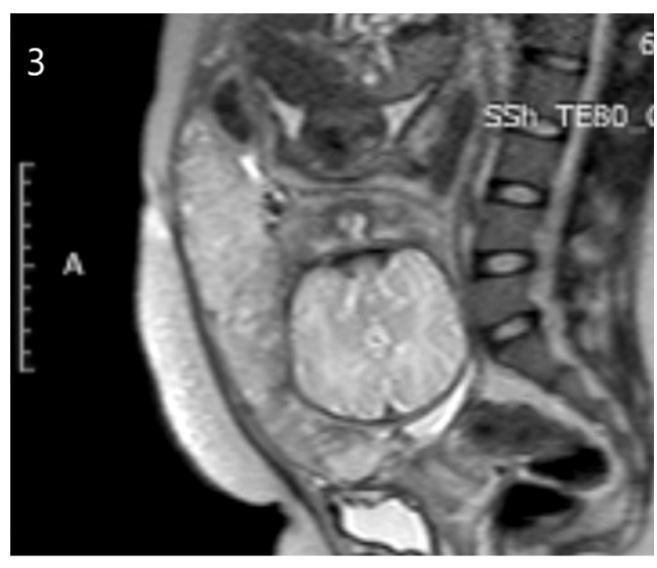

Fig. (3): A pregnant 43 years old female giving history of previous caesarian section with placenta previa marginalis and no evidence of accreta. Sagittal T2 WI's.

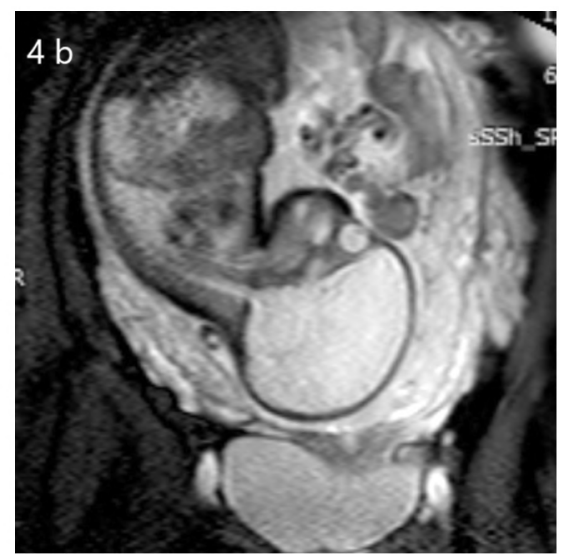

Fig. (4): A pregnant 42 years old female giving history of previous caesarian section with low lying placenta and no evidence of accreta. (A) Sagittal T2 WI's (B) Coronal spin echo WI's.

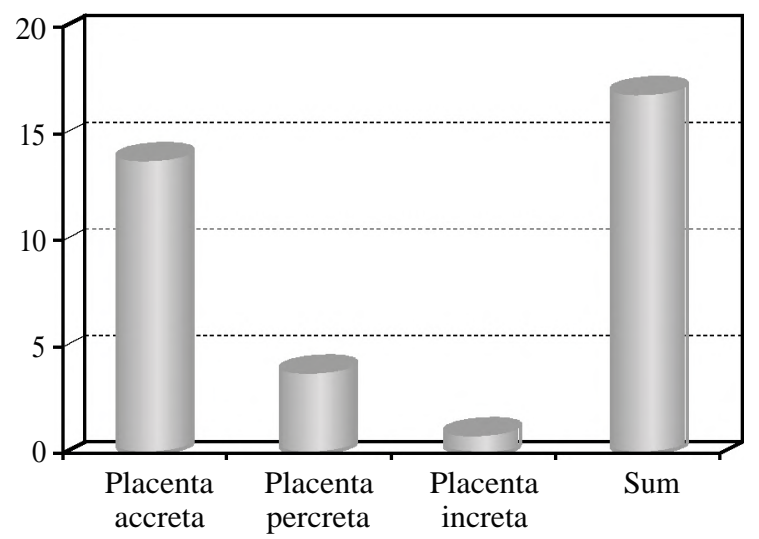

Fig. (5): Bar chart showing classification of placenta accreta cases according to their types.

Table (1): Classification of cases with placenta previa according to type.

\begin{tabular}{lcccc}
\hline $\begin{array}{l}\text { Cases with } \\
\text { placenta } \\
\text { previa }\end{array}$ & $\begin{array}{c}\text { Complete } \\
\text { centralis } \\
\text { type }\end{array}$ & $\begin{array}{c}\text { Partial } \\
\text { centralis } \\
\text { type }\end{array}$ & $\begin{array}{c}\text { Marginalis } \\
\text { type }\end{array}$ & $\begin{array}{c}\text { Low } \\
\text { lying } \\
\text { type }\end{array}$ \\
\hline 50 cases & 24 cases & 20 cases & 4 cases & 2 cases \\
\hline
\end{tabular}

After correlation with operative details and/or histopathology, MRI gave $100 \%$ positive results in cases diagnosed with placenta accreta (18 cases) while it gave true negative results in about $81 \%$ of cases (26 cases) and false negative in about $19 \%$ of cases (6 cases) with sensitivity $72.73 \%$, accuracy $86.96 \%$, and specificity $100 \%$.

\section{Discussion}

Placenta previa and previous cesarean sections are the major risk factors for PA with common postpartum hysterectomy [9]. Being of low-cost and owing to its accessibility ultrasound was the diagnostic modality of choice in placental assessment [5].

MRI emerged as a superior modality due to the limited ability of ultrasound in detection of depth of myometrial invasion in cases of placenta accreta and assessment of accreta in posterior wall placenta $[10,11]$ 
MRI was stated to be more efficient in abnormal placentation assessment by Teo et al. [12].

This study is a prospective study evaluating the efficiency of MRI in placenta accreta. We proved MRI study to have a sensitivity and specificity of $72.73 \%$ and $100 \%$ respectively in placenta accreta diagnosis in agreement with Warshak et al. [13], Masselli et al. [14] and Mansour and Khayat [15] yet conflicting with the results reported by of Dwyer et al. [16].

In agreement with Jakab et al., [17], spin echo sequences done in our study with controlled breath hold increased the specificity for MRI owing to the minimizing of motion artifacts resulting from the fetal motion and/or the mother respiration as well as the bowel peristaltic movements.

We agreed with Matsubara et al., [18] who stated that placenta previa centralis type was the commonest type of placenta previa as in our study this type represented $88 \%$ of cases (44 cases).

In this study, retro-placental clear space obliteration revealed the utmost sensitivity (64\%), second to it was the interruption of the interface between the posterior bladder wall and uterus (52\%) with low sensitivity regarding the presence of vascular lacunae. unlike Baughman et al., [9] who did not consider retro-placental clear space obliteration as a dependable sign if detected alone without other diagnostic criteria.

Our results are in concurrence with Varghese et al., [5], Lax et al., [7] and Algebally et al., [19] who stated that irregular thick intra-placental T2 dark bands as the most reliable sign of abnormal placentation on MRI. Other signs included heterogenous signal intensity of the placenta as well as bulging of the uterine lower segment, myometrial interruptions, tenting of the urinary bladder, and detection of invasion of pelvic structures [20].

We also agreed with Maurea et al., [11] who stated that placenta accreta type was the commonest type of placenta with abnormal placental invasion as in our study this type represented about $72 \%$ of cases with abnormal placental invasion (13 cases).

Operative details and/or histopathology confirmed the superiority and accuracy of MRI study in assessment of placenta accreta.

\section{Conclusion:}

MRI showed outstanding sensitivity and specificity in the detection as well as classification of placenta previa and placenta accreta thus providing more accurate diagnostic information with more favorable pregnancy and delivery outcomes.

\section{References}

1- K.M. ELSAYES, A.T. TROUT, A.M. FRIEDKIN, et al.: Imaging of the placenta: A multimodality pictorial review. Radiographics, 29: pp. 1371-91, 2009.

2- L.O. CHICHAKLI, H.K. ATRASH, A.P. MACKAY, et al.Pregnancy-related mortality in the United States due to hemorrhage: 1979-1992. Obstet. Gynecol., 94: p. 721, 1999.

3- OYDESA and SMULIAN: Placenta previa, placenta accreta, and vasa previa. Obstet. Gynecol., 107: pp. 92741, 2006.

4- C.H. TAN, K.H. TAY, K. SHEAH, et al.: Perioperative endovascular internal iliac artery occlusion balloon placement in management of placenta accreta. Am. J. Roentgenol., 189 (5): pp. 1158-63, 2007.

5- VARGHESE B., SINGH N., GEORGE R., et al.: Magnetic resonance imaging of placenta accrete. Indian J. Radiol. Imaging, 23 (4): 379-85, 2013.

6- E. JAUNIAUX and D. JURKOVIC: Placenta accreta: Pathogenesis of a 20 th century iatrogenic uterine disease Placenta, 30: pp. 244-51, 2012.

7- A. LAX, M.R. PRINCE, K.W. MENNITT, et al.: The value of specific MRI features in the evaluation of suspected placental invasion Magn. Reson. Imag., 25: pp. 87-93, 2007.

8- ANNA Y. DERMAN1, VIOLETA NIKAC, SHOSHANA HABERMAN, NATALIE ZELENKO, OLEG OPSHA andMARK FLYER: MRI of Placenta Accreta: A New Imaging Perspective, DOI: 10.2214/AJR.10.5443, A.J.R., 197: 1514-21, 2011.

9- W.C. BAUGHMAN, J.E. CORTEVILLE and R.R. SHAH: Placenta accreta: Spectrum of US and MR imaging findings. RadioGraphics, 28, pp. 1905-16, 2008.

10- G. LAM, J. KULLER and M. McMAHON: Use of magnetic resonance imaging and ultrasound in the antenatal diagnosis of placenta accrete. J. Soc. Gynecol. Invest., 9, pp. 37-40, 2002.

11-MAUREA S., ROMEO V., MAINENTI P.P., GINOCCHIO M.I., FRAUENFELDER G., VERDE F., LIUZZI R., D'ARMIENTO M., SARNO L., MORLANDO M., PETRETTA M., MARTINELLI P. and BRUNETTI A.: Diagnostic accuracy of magnetic resonance imaging in assessing placental adhesion disorder in patients with placenta previa: Correlation with histological findings. Eur. J. Radiol., Sep., 106: 77-84. doi: 10.1016/j.ejrad. 2018.07.014. Epub 2018 Jul 19, 2018.

12- T.H. TEO, Y.M. LAW, K.H. TAY, et al.: Use of magnetic resonance imaging in evaluation of placental invasion. Clin. Radiol., 64 (5), pp. 511-6, 2009.

13- C.R. WARSHAK, R. ESKANDER, A.D. HULL, A.L. SCIOSCIA, R.F. MATTREY, K. BENIRSCHKE, et al.: Accuracy of ultrasonography and magnetic resonance imaging in the diagnosis of placenta accreta. Obstet. Gynecol., 108, pp. 573-81, 2006. 
14- G. MASSELLI, R. BRUNELLI, E. CASCIANI, et al.: Magnetic resonance imaging in the evaluation of placental adhesive disorders: Correlation with color Doppler ultrasound. Eur. Radiol., 18: pp. 1292-9, 2008.

15- MANSOUR S.M. and ELKHAYAT W.M.: Placenta previa-accreta. Do we need MR imaging?. Egypt J. Radiol. Nucl. Med., 42: 433-43, 2011.

16- B.K. DWYER, V. BELOGOLOVKIN, L. TRAN, et al.: Prenatal diagnosis of placenta accreta: Sonography or magnetic resonance imaging? J. Ultrasound Med., 27: pp. $1275-81,2008$

17- JAKAB A., TUURA R.L., KOTTKE R., et al.: Microvascular perfusion of the placenta, developing fetal liver, and lungs assessed with intravoxel incoherent motion imaging. J. Magn. Reson. Imaging, doi 10.1002/ jmri.25933, 2017.
18- MATSUBARA S., TAKAHASHI H. and TAKEI Y.: Magnetic resonance imaging for diagnosis of placenta accreta spectrum disorders: Still useful for real-world practice. American Journal of Obstetrics and Gynecology, 219 (3): pp. 312-3, 2018.

19- ALGEBALLY AHMED M., REDA RAMADAN HUSSEIN YOUSEF, SANAA SAYED HUSSEIN BADR, AMAL AL OBEIDLY, WOJCIECH SZMIGIELSKI and ABDULLAH A. AL IBRAHIM: The Value of Ultrasound and Magnetic Resonance Imaging in Diagnostics and Prediction of Morbidity in Cases of Placenta Previa with Abnormal Placentation. DOI: 10.12659/PJR.891252. (C) Pol. J. Radiol., 79: 409-16, 2014

20- A.Y. DERMAN, V. NIKAC, S. HABERMAN, et al.: MRI of placenta accreta: A new imaging perspective. A.J.R., 197: pp. 1514-21, 2011

\section{دور التصوير بالرنين المغناطيسى

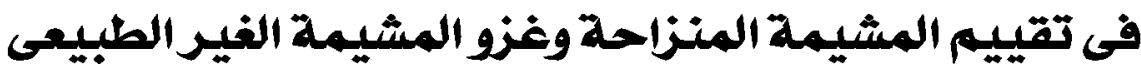

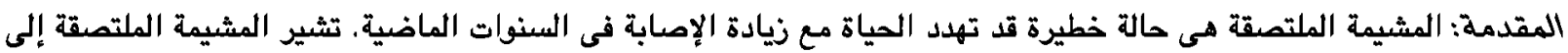

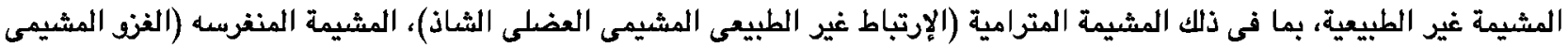

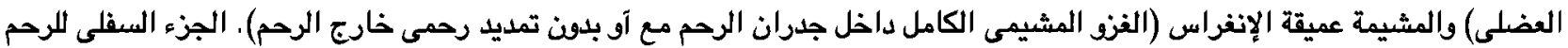

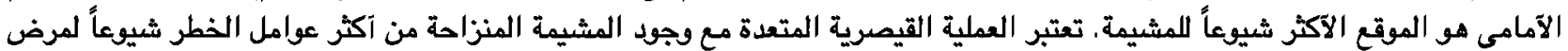

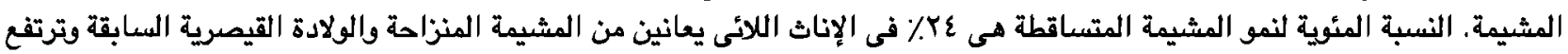
مع زيادة عدد الآقسام العابقة إلى العمليات القيصرية.

الهدف من هذه الدراسة: آجريت هذه الدراسة بهذف توضيح دور التصوير بالرنين المغناطيسى فى تقييم غزو جدران الرحم من قبل

$$
\text { المشيمة فى حالات المشيمة المنزاحة. }
$$

الوسائل والمرضى : دراسة مستقبلية ل .0 إمرآة حامل تتراوح آعمارهن بين مب وهـ عاماً. تم إحالتهم جميعاً إلى قسم آمراض النساء

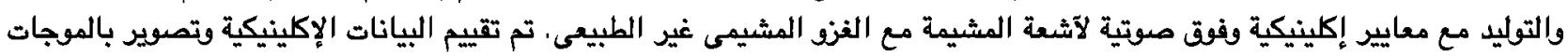
فقق الصوتية تليها دراسة التصوير بالرنين المغناطيسى للبطن والحوض لتئية التييم المشيمة.

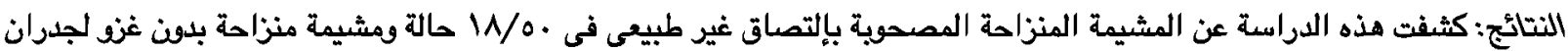

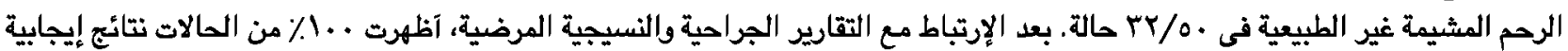

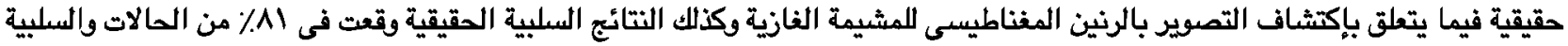

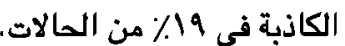

الإستستاج: تقدم دراسة التصوير بالرنين المغناطيسى خياراً ممتازاً لتقيم المشيمة المنزاحة والكشف عن الغزو المشيمى لجدران الرحم 